\title{
Fertilization with Nitrogen, Phosphorus, and Potassium Affects Composition of Araucaria angustifolia Needles, Branches and Stem
}

\author{
Valdeci Constantino ${ }^{1}$ (C) \\ Antônio Carlos Vargas Motta² \\ Julierme Zimmer Barbosa ${ }^{3}$ (1) \\ Eloá Moura Araujo ${ }^{2}$ (D) \\ Guilherme Quaresma Pedreira ${ }^{2}$ (1) \\ Flávio Zanette ${ }^{1}$ (1)
}

\begin{abstract}
Fertilization can be a sustainable management practice for the maintenance of the threatened species such as Araucaria angustifolia. Our objective was to evaluate the elemental composition of A. angustifolia fertilized with $\mathrm{N}$, $\mathrm{P}$, and $\mathrm{K}$, and how the fertilization altered the soil fertility. Seven-month-old seedlings were transplanted to $16 \mathrm{dm}^{3}$ soil pots, and three experiments were carried separately (one for each cited element) in a completely randomized design. Overall, the seedlings tended to accumulate nutrients differently among the compartments in the following order: needles $>$ branches $>$ stem. Application of $\mathrm{N}$ reduced the soil $\mathrm{pH}$, boosted $\mathrm{Mn}$ concentration in more 10 times, decreased the $\mathrm{P}$ uptake, and changed the C:N and C:P ratios. Increased doses of P led to higher uptake rates but promoted a reduction in the absorption of $\mathrm{Mg}$. High rates of $\mathrm{K}$ diminished of $\mathrm{P}, \mathrm{Ca}, \mathrm{Mg}, \mathrm{Mn}$, and $\mathrm{B}$, confirming antagonism interaction with $\mathrm{Ca}$ and $\mathrm{Mg}$.
\end{abstract}

Keywords: South American flora, macronutrients, nutrient deficiency, plant nutrition, nutrient ratio.

\section{INTRODUCTION}

Deforestation threatens the earth's biodiversity and the ecosystem services upon which humans depend (Rhodes et al., 2017). For instance, tropical vegetation provides a myriad of ecosystem services and at the same time is highly degraded (Martiniano et al., 2019). The Atlantic Forest is considered one of the most important biodiversity hotspots (Canei et al., 2018), characterized by areas that have lost $\geq 70 \%$ of their primary vegetation, and contain $\geq 1500$ endemic vascular plant species (Kobayashi et al., 2019).

Among the Atlantic Forest Biome phytophysiognomies, the Mixed Ombrophilous Forest (FOM) (the so-called Araucaria Forest) is one of the most threatened (Higuchi et al., 2012; Canei et al., 2018). In this environment, the native Araucaria angustifolia trees have been intensely exploited, stands to the point of accentuated reduction of its natural reserves in the late 1980s and is currently classified as vulnerable to extinction (Canei et al., 2018).

Formal regulation is a key mechanism by which governments seek to protect forests (Rhodes et al., 2017). However, scholars like Scheeren et al. (1999) and Hess et al. (2018) suggest that sustainable management is of utmost importance for future preservation, multiple-use, profitable production and enhancement of the Araucaria Forest in southern Brazil, being one more efficient way to conserve the remains of Araucaria Forest. However, for the management, socioenvironmental and socioeconomic maintenance, it is required the search for information that supports the elaboration of management plans based on models generated using multiple factors related to the species and the environment (Orellana \& Vanclay, 2018a, 2018b; Ricken et al., 2018).

Despite the importance of A. angustifolia, Canei et al. (2018) highlight there is little knowledge of its silvicultural

${ }^{1}$ Universidade Federal do Paraná, Departamento de Fitotecnia e Fitossanidade, Curitiba, PR, Brasil

${ }^{2}$ Universidade Federal do Paraná, Departamento de Solos e Engenharia Agrícola, Programa de Pós-graduação em Ciência do Solo, Curitiba, PR, Brasil

${ }^{3}$ Centro Universitário Ingá, Departamento de Agronomia, Maringá, PR, Brasil. 
requirements, specifically the planting techniques that favor the development of seedlings in the field. Thus, studies are needed relating to the edaphoclimatic conditions that can favor the success in A. angustifolia reforestation, since it is a native species with important ecosystem services. In this way, our objective was to evaluate the nutritional aspects of $A$. angustifolia fertilized with $\mathrm{N}, \mathrm{P}$ and $\mathrm{K}$, the elemental profile resulting from the nutrition of the species, and how the fertilization altered the soil fertility.

\section{MATERIAL AND METHODS}

The study was conducted in an outdoor nursery located in Curitiba - Paraná, Brazil (25 24'45.46" S; $49^{\circ} 14^{\prime} 55.15^{\prime \prime}$ $\mathrm{W}$; altitude $911 \mathrm{~m})$. Plastic pots $\left(20 \mathrm{dm}^{3}\right)$ were filled with $16 \mathrm{dm}^{3}$ of a Cambisol (Table 1) originally collected in an area of A. angustifolia natural occurrence (Pinhais County; latitude -25.38; longitude -49.12; altitude $920 \mathrm{~m}$ ). Further information about the experiment, may be seen in Constantino et al. (2019).

In summary, the soil (sieved $<4 \mathrm{~mm}$ ) was amended with $3.6 \mathrm{~g} \mathrm{~kg}^{-1}$ of dolomitic lime (75.2\% neutralizing power) to raise the base saturation to $70 \%$. After lime application, the soil was homogenized and incubated for two months.

Each of the three experiments in this study had five treatments, in which one element was applied in five rates, while fixed rates were applied for the other two nutrients. Experiment I: $\mathrm{N}\left(0,158,315,624\right.$, and $\left.1238 \mathrm{mg} \mathrm{dm}^{-3}\right)$, $\mathrm{P}$ (469 $\left.\mathrm{mg} \mathrm{dm}^{-3}\right)$, and $\mathrm{K}\left(469 \mathrm{mg} \mathrm{dm}^{-3}\right)$; Experiment II: $\mathrm{P}\left(0,117,234,469\right.$, and $\left.938 \mathrm{mg} \mathrm{dm}^{-3}\right), \mathrm{N}\left(624 \mathrm{mg} \mathrm{dm}^{-3}\right)$, and $\mathrm{K}\left(469 \mathrm{mg} \mathrm{dm}^{-3}\right)$; and Experiment III: $\mathrm{K}(0,117,234,469$, and $\left.938 \mathrm{mg} \mathrm{dm}^{-3}\right), \mathrm{N}\left(624 \mathrm{mg} \mathrm{dm}^{-3}\right)$, and $\mathrm{P}\left(469 \mathrm{mg} \mathrm{dm}^{-3}\right)$. Respective sources used to provide N, $\mathrm{P}$, and $\mathrm{K}$ was urea $(45 \% \mathrm{~N})$, triple superphosphate $\left(41 \% \mathrm{P}_{2} \mathrm{O}_{5}\right)$, and $\mathrm{K}$ chloride $\left(60 \% \mathrm{~K}_{2} \mathrm{O}\right)$. The rates of $\mathrm{N}$ indicated above correspond to the total amount used in the first and second year. Half was applied at the installation of the experiment (December 2013). The remainder was divided into three
$(25,15$, and $10 \%)$, applied every 60 days, starting December 2014. The experiments were carried out with four replicates in a completely randomized design.

Respective amounts of N (50 \% total amount), P, and K for each treatment were applied to $16 \mathrm{dm}^{3}$ of soil followed by homogenization before pot filling. Seven-month-old A. angustifolia seedlings (about $20 \mathrm{~cm}$ height) were transplanted to pots on $13^{\text {th }}$ December 2013. Pots were randomly distributed in the nursery and placed on a plastic surface to avoid contact with the underlying soil. Weed control was performed manually. Irrigation occurred as needed especially during periods of no rainfall by adding approximately two liters of water to each pot in the morning. In September 2015 (21-month after planting), plants were harvested and divided into needles, branches, and stems; each fraction was oven-dried $\left(60^{\circ} \mathrm{C}\right)$ and milled $(<1 \mathrm{~mm})$.

The vegetal samples were submitted to $6 \mathrm{~mL}$ of $\mathrm{HNO}_{3}+$ ultra-pure water solution $\left(2: 1 ; \mathrm{v} / \mathrm{v}\right.$ ratio) and $2 \mathrm{~mL}$ of $\mathrm{H}_{2} \mathrm{O}_{2}$ (30\%) in microwave-assisted digestion (MARS, CEM Microwave Technology Ltd). From the solution, P, Ca, Mg, $\mathrm{Fe}, \mathrm{Mn}, \mathrm{Zn}, \mathrm{Cu}, \mathrm{B}, \mathrm{Al}, \mathrm{Ba}, \mathrm{Cd}$, and $\mathrm{Ti}$ were determined using the optical emission spectrometer with inductively coupled plasma equipment (ICP-OES) (720-ES, Varian). To determine the elemental composition of $\mathrm{K}$, a flame emission spectrometer (DM-62, Digimed) was used. The level of $\mathrm{Ne}$ $\mathrm{C}$ was obtained from non-digested vegetal samples using an elementary analyzer (Vario EL III model, Elementar) only in the samples from Experiment I.

After the experiment, soil samples from each pot were collected, dry, ground, sieved and evaluated for chemical analysis according to Embrapa (2011).

Data were subjected to analysis of normality of the residues (Shapiro-Wilke test) variance $(\mathrm{p}<0.05)$, and effects of $\mathrm{N}, \mathrm{P}$, and $\mathrm{K}$ rates were determined by regression analysis. The choice of regressions (linear or quadratic) was based on the highest coefficient of determination $\left(\mathrm{R}^{2}\right)$ and probability $(\mathrm{p})$ values. For all analyses, the statistical software Assistat 7.7 was used.

Table 1. Granulometric and chemical properties of the soil before planting Araucaria angustifolia seedlings ${ }^{1}$.

\begin{tabular}{|c|c|c|c|c|c|c|c|c|c|c|c|c|}
\hline Liming & Clay $^{1}$ & pH & $\mathrm{Ca}^{2+}$ & $\mathrm{Mg}^{2+}$ & $\mathbf{K}^{+}$ & $\mathbf{A l}^{3+}$ & $\mathbf{H}+\mathbf{A l}$ & CEC & $\mathbf{V}$ & $\mathbf{m}$ & $\mathbf{P}$ & OC \\
\hline & $\mathrm{kg}^{-1}$ & & & -..-. & --- cn & $\mathrm{dm}^{-3}$ & ----- & & $\%$ & $\%$ & $\mathrm{mg} \mathrm{dm^{-3 }}$ & $\mathrm{g} \mathrm{dm}^{-3}$ \\
\hline Before & 550 & 4.0 & 1.60 & 0.80 & 0.08 & 2.90 & 11.30 & 13.78 & 18 & 54 & 0.9 & 4.2 \\
\hline After $^{2}$ & --- & 5.5 & 4.17 & 3.25 & 0.07 & 0.00 & 5.58 & 13.50 & 55 & 0 & 1.4 & 6.6 \\
\hline
\end{tabular}

${ }^{1}$ Prior to analysis, soil was sieved $(2 \mathrm{~mm})$ and dried at $40^{\circ} \mathrm{C}$ to determine: sand, silt, and clay (hydrometer method); $\mathrm{pH}\left(\mathrm{CaCl}_{2} 0.01 \mathrm{~mol} \mathrm{~L}^{-1}\right) ; \mathrm{Ca}^{2+}, \mathrm{Mg}^{2+}, \mathrm{Al}^{3+}(\mathrm{extracted}$ with $\mathrm{KCl} 1 \mathrm{~mol} \mathrm{~L}^{-1}$ ); $\mathrm{H}+\mathrm{Al}$ (calcium acetate $0.5 \mathrm{~mol} \mathrm{~L}^{-1}$ extraction); organic carbon (OC) (volumetric method by potassium dichromate); $\mathrm{K}^{+}$and $\mathrm{P}$ (Mehlich-1 extraction); base saturation (V); cation exchange capacity (CEC) at $\mathrm{pH} 7$; and $\mathrm{Al}^{3+}$ saturation $(\mathrm{m} \%) .{ }^{2} \mathrm{Chemical}$ characterization of the soil after the lime application. 


\section{RESULTS AND DISCUSSION}

\subsection{Effect of the $N$ fertilization}

The effectiveness of the lime was evident (Table 1). However, as $\mathrm{N}$ rates increased, there was a gradual reduction of the soil $\mathrm{pH}$, making the soil more acidic, what may interfere with the assimilation of the other elements [Table 2 - also presented in Constantino et al. (2019)]. Studying the soil $\mathrm{pH}$ in planted forests in Northern China, Hong et al. (2019) found that $\mathrm{N}$ deposition affect directly and indirectly the soil $\mathrm{pH}$. $\mathrm{NH}_{4}^{+}$can replace the base cations, promoting the bases leaching and soil acidification (Hong et al., 2019), or through acidification of the rhizosphere via $\mathrm{H}^{+}$extrusion and nitrification process, or even by the organic acid production as a consequence of organic matter decomposition under high $\mathrm{N}$ application rates (Ata-Ul-Karim et al., 2020).

The application of $\mathrm{N}$ also had a reflection on the nutrient levels in needles, branches, and stem (Table 3 ). The $\mathrm{N}$ levels on needles increased 90\%, while the levels in branches and stem increased less than $50 \%$ when compared the highest rate with the control treatment.

Table 2. Values of $\mathrm{pH}, \mathrm{C}, \mathrm{P}$, and $\mathrm{K}$ after harvesting Araucaria angustifolia seedlings, submitted five rates of N, $\mathrm{P}$ and $\mathrm{K}$ fertilization. ${ }^{1}$

\begin{tabular}{|c|c|c|c|c|c|c|c|c|c|c|c|c|c|c|c|}
\hline \multirow{2}{*}{ Variables } & \multicolumn{5}{|c|}{----Rates of $\mathbf{N}\left(\mathrm{mg} \mathrm{dm}^{-3}\right)$------- } & \multicolumn{5}{|c|}{-----Rates of $P\left(\mathrm{mg} \mathrm{dm}^{-3}\right)$----- } & \multicolumn{5}{|c|}{----Rates of $\mathrm{K}\left(\mathrm{mg} \mathrm{dm}^{-3}\right)$----- } \\
\hline & 0 & 158 & 315 & 624 & 1238 & $\mathbf{0}$ & 118 & 233 & 469 & 938 & $\mathbf{0}$ & 117 & 234 & 469 & 938 \\
\hline $\mathrm{pH}-\mathrm{CaCl}_{2}$ & 5.5 & 5.6 & 5.3 & 4.6 & 4.3 & 4.8 & 5.0 & 4.9 & 4.8 & 4.8 & 4.4 & 4.7 & 4.9 & 4.8 & 4.5 \\
\hline Carbon $\left(\mathrm{g} \mathrm{dm}^{-3}\right)$ & 6.7 & 5.1 & 10.6 & 7.8 & 10 & 4.3 & 4.7 & 5.8 & 6.8 & 3.0 & 8.9 & 8.7 & 8.4 & 10.7 & 9.5 \\
\hline $\mathrm{P}\left(\mathrm{mg} \mathrm{dm^{-3 }}\right)$ & 30.0 & 35.4 & 37.9 & 45.6 & 34.7 & 1.4 & 7.5 & 16.4 & 58.2 & 135.6 & 34.8 & 43.6 & 42.7 & 43.5 & 50.1 \\
\hline $\mathrm{K}^{+}\left(\mathrm{cmol} \mathrm{dm}^{-3}\right)$ & 0.50 & 0.48 & 0.42 & 0.30 & 0.21 & 0.41 & 0.38 & 0.45 & 0.37 & 0.33 & 0.07 & 0.11 & 0.15 & 0.28 & 0.69 \\
\hline
\end{tabular}

${ }^{1} \mathrm{pH}\left(\mathrm{CaCl}_{2} 0.01 \mathrm{~mol} \mathrm{~L}^{-1}\right)$; organic carbon $(\mathrm{OC})$ (volumetric method by potassium dichromate); and $\mathrm{K}^{+}$and $\mathrm{P}$ (Mehlich-1 extraction).

Table 3. Elemental composition of Araucaria angustifolia needles, branches and stem in response to nitrogen fertilization.

\begin{tabular}{|c|c|c|c|c|c|c|c|c|c|c|c|c|c|c|c|}
\hline \multirow{3}{*}{ Var. } & \multicolumn{5}{|c|}{ Rates of $\mathbf{N}\left(\mathrm{mg} \mathrm{dm}^{-3}\right)$} & \multirow{2}{*}{ Eq. } & \multirow{2}{*}{$\mathbf{R}^{2}$} & \multirow{2}{*}{ Var. } & \multicolumn{5}{|c|}{ Rates of $\mathbf{N}\left(\mathrm{mg} \mathrm{dm}^{-3}\right)$} & \multirow{3}{*}{ Eq. } & \multirow[b]{2}{*}{$\mathbf{R}^{2}$} \\
\hline & $\mathbf{0}$ & 158 & 315 & 624 & 1238 & & & & $\mathbf{0}$ & 158 & 315 & 624 & 1238 & & \\
\hline & \multicolumn{13}{|c|}{ 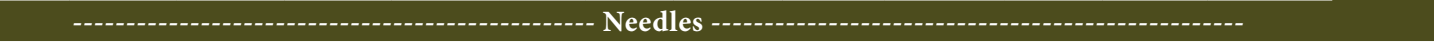 } & & \\
\hline $\mathrm{C} / \mathrm{N}$ & 58 & 51 & 52 & 36 & 32 & $\mathrm{~L}^{* *}$ & 0.87 & $\mathrm{Mn}$ & 35 & 46 & 47 & 193 & 330 & $\mathrm{Q}^{* *}$ & 0.96 \\
\hline $\mathrm{C} / \mathrm{P}$ & 137 & 239 & 267 & 291 & 276 & $\mathrm{~L}^{* *}$ & 0.44 & $\mathrm{Zn}$ & 21 & 18 & 13 & 16 & 18 & $\mathrm{Q}^{*}$ & 0.64 \\
\hline $\mathrm{C}$ & 457 & 465 & 473 & 480 & 472 & ns & - & $\mathrm{Cu}$ & 1.6 & 2.1 & 1.9 & 3.3 & 2.4 & $\mathrm{~L}^{*}$ & 0.29 \\
\hline $\mathrm{N}$ & 7.9 & 10.0 & 9.0 & 13.0 & 15.0 & $\mathrm{~L}^{* *}$ & 0.88 & B & 15 & 10 & 9.5 & 11 & 11 & ns & - \\
\hline $\mathrm{P}$ & 3.4 & 2.2 & 1.8 & 1.7 & 1.8 & $\mathrm{~L}^{* *}$ & 0.41 & $\mathrm{Al}$ & 103 & 84 & 81 & 75 & 72 & $L^{* *}$ & 0.65 \\
\hline K & 14 & 13 & 19 & 17 & 13 & ns & - & $\mathrm{Ba}$ & 14 & 11 & 11 & 15 & 16 & ns & - \\
\hline $\mathrm{Ca}$ & 8.5 & 7.6 & 7.4 & 8.9 & 9.2 & ns & - & $\mathrm{Cd}$ & 0.03 & 0.02 & 0.05 & 0.11 & 0.10 & $\mathrm{~L}^{* *}$ & 0.69 \\
\hline $\mathrm{Mg}$ & 3.2 & 3.2 & 3.0 & 2.9 & 3.1 & ns & - & $\mathrm{Ti}$ & 1.4 & 1.3 & 1.2 & 1.6 & 1.4 & ns & - \\
\hline $\mathrm{Fe}$ & 91 & 82 & 81 & 84 & 90 & ns & & & & & & & & & \\
\hline & & & & & & & Bran & & & & & & & & \\
\hline $\mathrm{C} / \mathrm{N}$ & 103 & 93 & 89 & 75 & 72 & $\mathrm{~L}^{* *}$ & 0.84 & $\mathrm{Mn}$ & 18 & 32 & 44 & 113 & 189 & $\mathrm{Q}^{\star *}$ & 0.98 \\
\hline $\mathrm{C} / \mathrm{P}$ & 189 & 296 & 374 & 336 & 334 & $\mathrm{~L}^{*}$ & 0.28 & $\mathrm{Zn}$ & 33 & 24 & 17 & 15 & 17 & $\mathrm{~L}^{* *}$ & 0.47 \\
\hline C & 445 & 446 & 446 & 448 & 443 & ns & - & $\mathrm{Cu}$ & 2.2 & 2.1 & 1.8 & 1.8 & 2.0 & ns & - \\
\hline $\mathrm{N}$ & 4.4 & 5.1 & 5.0 & 6.1 & 6.3 & $\mathrm{~L}^{* *}$ & 0.83 & B & 21 & 15 & 15 & 13 & 12 & $\mathrm{~L}^{* *}$ & 0.63 \\
\hline $\mathrm{P}$ & 2.4 & 1.9 & 1.3 & 1.5 & 1.4 & $\mathrm{~L}^{*}$ & 0.45 & $\mathrm{Al}$ & 129 & 91 & 116 & 100 & 96 & ns & - \\
\hline K & 12 & 10 & 10 & 14 & 10 & ns & - & $\mathrm{Ba}$ & 26 & 22 & 23 & 24 & 27 & $\mathrm{Q}^{*}$ & 0.67 \\
\hline $\mathrm{Ca}$ & 9.4 & 8.0 & 7.4 & 7.7 & 7.8 & ns & - & $\mathrm{Cd}$ & 0.15 & 0.11 & 0.16 & 0.31 & 0.23 & $\mathrm{~L}^{*}$ & 0.40 \\
\hline $\mathrm{Mg}$ & 3.2 & 3.3 & 2.9 & 3.0 & 2.9 & $\mathrm{Q}^{*}$ & 0.58 & $\mathrm{Ti}$ & 2.3 & 1.5 & 2.4 & 1.5 & 2.0 & ns & - \\
\hline $\mathrm{Fe}$ & 122 & 86 & 108 & 79 & 95 & ns & - & & & & & & & & \\
\hline & & & & & & & SteI & & & & & & & & \\
\hline $\mathrm{C} / \mathrm{N}$ & 116 & 111 & 107 & 84 & 76 & $\mathrm{~L}^{* *}$ & 0.91 & $\mathrm{Mn}$ & 12 & 23 & 28 & 85 & 123 & $\mathrm{Q}^{\star *}$ & 0.95 \\
\hline $\mathrm{C} / \mathrm{P}$ & 276 & 316 & 424 & 402 & 453 & $\mathrm{~L}^{*}$ & 0.69 & $\mathrm{Zn}$ & 13 & 20 & 10 & 11 & 11 & ns & - \\
\hline C & 453 & 446 & 443 & 445 & 440 & $\mathrm{~L}^{* *}$ & 0.65 & $\mathrm{Cu}$ & 1.8 & 2.4 & 1.8 & 2.4 & 2.3 & ns & - \\
\hline $\mathrm{N}$ & 3.9 & 4.2 & 4.2 & 5.5 & 5.8 & $\mathrm{~L}^{* *}$ & 0.87 & B & 11.0 & 10.0 & 8.1 & 11.0 & 9.4 & ns & - \\
\hline $\mathrm{P}$ & 1.7 & 1.6 & 1.1 & 1.3 & 1.0 & $\mathrm{~L}^{*}$ & 0.65 & $\mathrm{Al}$ & 47 & 42 & 36 & 25 & 30 & ns & - \\
\hline K & 9.8 & 9.0 & 7.5 & 7.6 & 8.6 & ns & - & $\mathrm{Ba}$ & 20 & 24 & 19 & 21 & 23 & ns & - \\
\hline $\mathrm{Ca}$ & 5.4 & 5.7 & 4.4 & 5.5 & 5.1 & ns & - & $\mathrm{Cd}$ & 0.10 & 0.10 & 0.20 & 0.20 & 0.10 & ns & - \\
\hline $\mathrm{Mg}$ & 2.2 & 3.0 & 2.3 & 2.8 & 2.7 & ns & - & $\mathrm{Ti}$ & 0.3 & 0.6 & 0.4 & 0.7 & 0.3 & ns & - \\
\hline $\mathrm{Fe}$ & 29 & 33 & 27 & 65 & 26 & ns & - & & & & & & & & \\
\hline
\end{tabular}

Where: $\mathrm{C}, \mathrm{N}, \mathrm{P}, \mathrm{K}, \mathrm{Ca}$ and $\mathrm{Mg}$ in $\mathrm{g} \mathrm{kg}^{-1} ; \mathrm{Fe}, \mathrm{Mn}, \mathrm{Zn}, \mathrm{Cu}, \mathrm{B}, \mathrm{Al}, \mathrm{Ba}, \mathrm{Cd}$ and Ti in $\mathrm{mg} \mathrm{kg}^{-1}$; Var. = variable; Eq = equation; $\mathrm{L}=$ linear equation; $\mathrm{Q}=\mathrm{quadratic}$ equation; ${ }^{*}$ denotes $\mathrm{p}<0.05$; ${ }^{* *}$ denotes $\mathrm{p}<0.01 ; \mathrm{ns}$ (no significant). 
While the $\mathrm{N}$ levels increased and the P levels decreased, the $\mathrm{C}$ concentration remained steady. As a consequence, the $\mathrm{C}: \mathrm{N}$ ratio decreased, and C:P ratio increased as function of the $\mathrm{N}$ application (Table 3). This pattern occurred in all the evaluated plant tissues. The C:N and C:P ratios were higher in stem, followed by branches. The ratios were about two times lowers in the needles, evidencing that these tissues would have a much lower turnover time when comparing to more fibrous tissues.

The linear response suggests that $\mathrm{N}$ and $\mathrm{P}$ concentration in the plant tissues is dependent on the rates used in the treatments. Probably, the structural and functional characteristics of each segment in the plant resulted in greater or lesser sensitivity to $\mathrm{N}$ supply. The order of largest to lowest $\mathrm{N}$ and $\mathrm{P}$ concentration found in the plant is as follows: needles $>$ branches $>$ stem. The high $\mathrm{N}$ input stimulates tree growth (Constantino et al., 2019), but it can be also accompanied by increasing foliar $\mathrm{N}: \mathrm{P}$ ratios (Table 3), that might imply the beginning of $\mathrm{P}$ deficiency in a longterm perspective, depleting the $\mathrm{P}$ reserves of the wood (Netzer et al., 2019).

The $\mathrm{N}$ and $\mathrm{P}$ have synergistic interactions that require a relatively constant proportion to catalyze metabolic reactions and synthesize essential compounds with specific N:P ratios (Yuan \& Chen, 2015). However, elevated inputs of either $\mathrm{N}$ or $\mathrm{P}$ may implicate shifts in nutrient cycles and nutrient balance (Peñuelas et al., 2012). The decreased plant $P$ concentration under $\mathrm{N}$ addition, as observed in Table 3, may not be simply related to decreasing availability of $\mathrm{P}$, but due to the massive imbalance in soil availability of $\mathrm{N}$ and $\mathrm{P}$ with greater $\mathrm{N}$ input, which stimulates plant to take up more $\mathrm{N}$ but limit $\mathrm{P}$ uptake (Deng et al., 2017).

The observed P concentration (Table 3) of needles are under normal level, since Simões \& Couto (1973) found the concentration of $2.3 \mathrm{~g} \mathrm{~kg}^{-1}$ of $\mathrm{P}$ in above-ground tissues of $A$. angustifolia seedling submitted to full fertilization. In the same experiment, authors found that when submitted to fertilization minus $P$, the seedlings presented $1.0 \mathrm{~g} \mathrm{~kg}^{-1}$ of $\mathrm{P}$ in the above-ground tissue of one-year-old seedling. So, it was unlike that there was a lack of $\mathrm{P}$ for plant growth and did no compromise the $\mathrm{N}$ response.

In general, the other macronutrients $(\mathrm{K}, \mathrm{Ca}$ and $\mathrm{Mg}$ ) were not affected by the treatments with $\mathrm{N}$, except for $\mathrm{Mg}$ which responded quadratically in the branches. The observed concentrations for needles can be considered normal since 7.2, 7.6 and $2.1 \mathrm{~g} \mathrm{~kg}^{-1}$ were observed for above-ground tissue by Simões \& Couto (1973). Again, there was no indication of $\mathrm{K}, \mathrm{Ca}$ and $\mathrm{Mg}$ deficiency. This was expected due to high level observed on soil evaluation (Tables 1 and 2).

Among the micronutrients, the answer to $\mathrm{N}$ application was erratic. The $\mathrm{Mn}$ was the most sensitive to $\mathrm{N}$ fertilization, presenting quadratic response in needles, branches, and stem. The highest concentration of the element was found in the needles ( $\left.330 \mathrm{mg} \mathrm{kg}^{-1}\right)$, followed by the branches $\left(189 \mathrm{mg} \mathrm{kg}^{-1}\right)$ and stem $\left(123 \mathrm{mg} \mathrm{kg}^{-1}\right)$. The decrease in $\mathrm{pH}$ due to $\mathrm{N}$ application could explain this variation since $\mathrm{Mn}$ has been shown to be the most sensibility to variation on foliar concentration among the other micronutrients $(\mathrm{Fe}, \mathrm{Cu}$, $\mathrm{Zn}, \mathrm{Ni}$ ) and $\mathrm{Al}$ which have they availability inverse related to $\mathrm{pH}$ (Motta et al., 2007).

The Mn increment was not only boosted in all plant tissue but also impressed by the magnitude of increment with more than tenfold augment. Despite, the high increment on $\mathrm{Mn}$ concentration the observed values are in the range $200-560 \mathrm{mg} \mathrm{kg}^{-1}$ of Mn for heathy growth tree (Blum, 1980). In a pioneer work, De Hoog (1981) found in most of the sites sampled Mn contents between 100 and $700 \mathrm{mg} \mathrm{kg}^{-1}$. The obtained increment of $\mathrm{Mn}$ should not result in plant toxicity for A. angustifolia trees, similar to what was observed for species from the same habitat of $A$. angustifolia like Ilex paraguariensis, Mimosa scabrella, Persea major, Quillaja brasiliensis, Sloanea lasiocoma and Vernonia discolor (Barbosa et al., 2018; Caldeira et al., 2006).

The change on soil acidity due to $\mathrm{N}$ application could also explain the enhancement on concentration of $\mathrm{Cu}$ by the needles, in the opposite, the concentrations of $\mathrm{Al}$ (in the needles) and $\mathrm{Zn}$ (needles and branches) decreased as response to $\mathrm{N}$ application, maybe in function of the elevated Mn uptake (Motta et al., 2007). The B and Ba only responded to the supply of $\mathrm{N}$ in the branches segment, with decreasing assimilation. Koohkan \& Maftoun (2016) also found negative relation between $\mathrm{B}$ and $\mathrm{N}$ in the shoot of Brassica napus $\mathrm{L}$., probably due to a dilution effect. $\mathrm{Cd}$ had a linear increase in concentration only in the needles and branches. Overall, the treatments had practically no effect on the elemental composition of the A. angustifolia stems.

\subsection{Effect of P fertilization}

The application of superphosphate had no effect on the soil pH (Table 2). So, we hypothesized that the differences in the elemental composition are mainly driven by the interactions between the elements (Table 4) and plant growth (Constantino et al. 2019). In addition, high 
phosphate fertilization reduces mycorrhizal colonization in A. angustifolia (Moreira-Souza \& Cardoso, 2002), which may contribute to reduce nutrient absorption.

$\mathrm{P}$ concentration in the needles, branches and stems linearly increased in function of the treatments. Branches were responsive, presenting approximately a 3 -fold increase, while the $\mathrm{P}$ concentration in needles and stems were up to $71 \%$ higher than in the control treatment. $P$ was accumulated in the order: needles $>$ branches $>$ stem. Barbosa et al. (2019) found higher P concentrations (2.77 to $5.99 \mathrm{~g} \mathrm{~kg}^{-1}$ ) in A. angustifolia seeds, indicating probable remobilization of the nutrient, especially of the needles and part of the branches, which fall during the winter.

The response of the other nutrients and heavy metals was erratic (Table 4). The elemental composition of the needles was less subjected to changes, while branches and stems were more responsive to the $\mathrm{P}$ application. $\mathrm{Mg}$ was the only nutrient that presented a consistent and negative response to the $\mathrm{P}$ application on all plant fractions (needles, branches, and stem). K was linearly affected in branches and stems, with a reduction of about $30 \%$. The interaction between $\mathrm{P}$ and $\mathrm{Ba}$ was significant and linear in all the plant fractions. In this case, the $\mathrm{P}$ application induced a reduction 42,47 , and $59 \%$ of the Ba levels in the needles, branches, and stem, respectively. This response similarity of $\mathrm{Ba}$ and $\mathrm{Mg}$ may be due to both being alkaline earth metals, that is, they may have similar plant metabolism aspects.

In the stem, the concentration of Ca linearly decreased with the $\mathrm{P}$ fertilization. Ca is a major constituent of cell walls, being largely immobile in wood tissue. Therefore, other elements may be referenced against $\mathrm{Ca}$ to indicate changes in their relative availability (Kohler et al., 2019). In the control treatment, Ca:P ratio in the stems was 11 , at the highest $\mathrm{P}$ rate, the ratio was 4 , reinforcing the substantial increase in the $P$ availability.

Table 4. Elemental composition of Araucaria angustifolia needles, branches and stem in response to phosphorous fertilization.

\begin{tabular}{|c|c|c|c|c|c|c|c|c|c|c|c|c|c|c|c|}
\hline \multirow[b]{2}{*}{ Var. } & \multicolumn{5}{|c|}{ Rates of $\mathbf{P}\left(\mathrm{mg} \mathrm{dm}^{-3}\right)$} & \multirow{2}{*}{ Eq. } & \multirow{2}{*}{$\mathbf{R}^{2}$} & \multirow{2}{*}{ Var. } & \multicolumn{5}{|c|}{ Rates of $\mathbf{P}\left(\mathbf{m g ~ d m} \mathbf{m}^{-3}\right)$} & \multirow[b]{2}{*}{ Eq. } & \multirow[b]{2}{*}{$\mathbf{R}^{2}$} \\
\hline & $\mathbf{0}$ & 117 & 234 & 469 & 938 & & & & $\mathbf{0}$ & 117 & 234 & 469 & 938 & & \\
\hline & \multicolumn{14}{|c|}{ 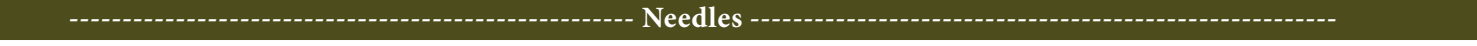 } & \\
\hline $\mathrm{P}$ & 1.11 & 1.48 & 1.50 & 1.54 & 1.79 & $\mathrm{~L}^{\star *}$ & 0.77 & $\mathrm{Cu}$ & 2.57 & 2.41 & 5.52 & 1.91 & 1.94 & ns & - \\
\hline K & 14 & 15 & 15 & 14 & 13 & ns & - & B & 12.00 & 8.58 & 10.13 & 8.13 & 10.00 & ns & - \\
\hline $\mathrm{Ca}$ & 9.02 & 9.06 & 8.90 & 7.80 & 7.66 & ns & - & $\mathrm{Al}$ & 98 & 94 & 121 & 69 & 75 & ns & - \\
\hline $\mathrm{Mg}$ & 2.90 & 3.55 & 3.40 & 3.17 & 2.94 & $\mathrm{Q}^{* *}$ & 0.43 & $\mathrm{Ba}$ & 19 & 16 & 16 & 14 & 11 & $\mathrm{~L}^{\star}$ & 0.93 \\
\hline $\mathrm{Fe}$ & 104 & 103 & 106 & 72 & 79 & ns & - & $\mathrm{Cd}$ & 0.09 & 0.09 & 0.07 & 0.06 & 0.11 & ns & - \\
\hline $\mathrm{Mn}$ & 184 & 125 & 95 & 141 & 103 & $\mathrm{~L}^{*}$ & 0.29 & $\mathrm{Ti}$ & 1.83 & 1.87 & 2.01 & 0.94 & 1.27 & $\mathrm{~L}^{*}$ & 0.47 \\
\hline $\mathrm{Zn}$ & 16 & 14 & 13 & 13 & 14 & ns & - & & & & & & & & \\
\hline & & & & & & --- & inch & 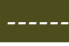 & S-A. & 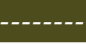 & 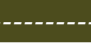 & 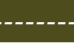 & & & \\
\hline $\mathrm{P}$ & 0.50 & 0.90 & 0.97 & 1.22 & 1.33 & $\mathrm{~L}^{* *}$ & 0.78 & $\mathrm{Cu}$ & 2.14 & 2.26 & 1.96 & 1.61 & 1.84 & ns & - \\
\hline K & 15 & 13 & 11 & 12 & 11 & $\mathrm{~L}^{*}$ & 0.5 & B & 18 & 14 & 13 & 13 & 13 & $L^{* *}$ & 0.38 \\
\hline $\mathrm{Ca}$ & 8.67 & 8.45 & 8.17 & 7.12 & 7.60 & ns & - & $\mathrm{Al}$ & 122 & 144 & 160 & 114 & 132 & ns & - \\
\hline $\mathrm{Mg}$ & 3.87 & 3.23 & 3.27 & 2.96 & 2.59 & $\mathrm{~L}^{* *}$ & 0.83 & $\mathrm{Ba}$ & 38 & 31 & 31 & 26 & 20 & $\mathrm{~L}^{* *}$ & 0.92 \\
\hline $\mathrm{Fe}$ & 125 & 142 & 153 & 115 & 129 & ns & - & $\mathrm{Cd}$ & 0.05 & 0.08 & 0.12 & 0.20 & 0.23 & $\mathrm{~L}^{* *}$ & 0.89 \\
\hline $\mathrm{Mn}$ & 125 & 85 & 68 & 111 & 95 & $\mathrm{Q}^{*}$ & 0.12 & $\mathrm{Ti}$ & 2.93 & 3.42 & 3.53 & 2.34 & 2.80 & ns & - \\
\hline $\mathrm{Zn}$ & 20 & 15 & 16 & 14 & 17 & ns & - & & & & & & & & \\
\hline $\mathrm{P}$ & 0.59 & 0.70 & 0.92 & 0.82 & 1.01 & $\mathrm{~L}^{*}$ & 0.7 & $\mathrm{Cu}$ & 2.60 & 1.93 & 2.05 & 1.73 & 1.83 & $L^{* *}$ & 0.43 \\
\hline K & 11.00 & 9.02 & 7.13 & 6.86 & 7. 34 & $\mathrm{~L}^{* *}$ & 0.8 & B & 14.00 & 10.00 & 10.00 & 8.38 & 8.62 & $\mathrm{~L}^{* *}$ & 0.52 \\
\hline $\mathrm{Ca}$ & 6.44 & 4.74 & 5.37 & 4.06 & 4.63 & $\mathrm{~L}^{* *}$ & 0.37 & $\mathrm{Al}$ & 30 & 26 & 27 & 25 & 15 & $\mathrm{~ns}$ & - \\
\hline $\mathrm{Mg}$ & 3.32 & 2.59 & 2.87 & 2.24 & 2.16 & $\mathrm{~L}^{* *}$ & 0.68 & $\mathrm{Ba}$ & 34 & 21 & 25 & 19 & 14 & $\mathrm{~L}^{* *}$ & 0.71 \\
\hline $\mathrm{Fe}$ & 29 & 23 & 28 & 31 & 50 & ns & - & $\mathrm{Cd}$ & 0.05 & 0.06 & 0.09 & 0.12 & 0.20 & $L^{* *}$ & 0.99 \\
\hline $\mathrm{Mn}$ & 61 & 45 & 36 & 61 & 44 & ns & - & $\mathrm{Ti}$ & 0.44 & 0.32 & 0.28 & 0.23 & 0.34 & ns & - \\
\hline $\mathrm{Zn}$ & 12.00 & 9.31 & 10.00 & 8.21 & 9.41 & ns & - & & & & & & & & \\
\hline
\end{tabular}

Where: $\mathrm{P}, \mathrm{K}, \mathrm{Ca}$ and $\mathrm{Mg}$ in $\mathrm{g} \mathrm{kg}^{-1} ; \mathrm{Fe}, \mathrm{Mn}, \mathrm{Zn}, \mathrm{Cu}, \mathrm{B}, \mathrm{Al}, \mathrm{Ba}, \mathrm{Cd}$ and $\mathrm{Ti}$ in $\mathrm{mg} \mathrm{kg}^{-1}$; Var. = variable; $\mathrm{Eq}$ = equation; $\mathrm{L}=$ linear equation; $\mathrm{Q}=$ quadratic equation; ${ }^{*}$ denotes $p<0.05$; ${ }^{* *}$ denotes $p<0.01$; ns (no significant). 


\subsection{Effect of $K$ fertilization}

The $\mathrm{K}$ was accumulated in the order: needles $>$ stem $>$ branches (Table 5). The application of $\mathrm{K}$ chloride had a quadratic effect over all the macronutrients in the A. angustifolia needles. The highest concentration of $\mathrm{K}$ in the needles $\left(15 \mathrm{mg} \mathrm{kg}^{-1}\right)$ was reached at the rate $469 \mathrm{mg} \mathrm{dm}^{-3}$ of K, but the rates 234 and $938 \mathrm{mg}$ $\mathrm{dm}^{-3} \mathrm{had}$ similar results, indicating a possible stabilization. Rates higher than $234 \mathrm{mg} \mathrm{dm}^{-3}$ of $\mathrm{K}$ reduced the concentration of $\mathrm{P}$ (34\%), $\mathrm{Ca}(70 \%)$, and $\mathrm{Mg}(51 \%)$. Mn, B, and Ba also had their levels in the needles reduced by the $\mathrm{K}$ application. Considering that fertilization was performed using $\mathrm{KCl}$, probably the decrease in absorption of cationic and anionic nutrients occurred due to the increase in the soil availability of $\mathrm{K}$ and $\mathrm{Cl}$, respectively.

The element $\mathrm{K}$ is rarely a minimum growth-limiting nutrient in forests growing on mineral soils due to recycle potential offered by the litter (Sarkkola et al., 2016). However, our results show that the fertilization influence the absorption of other nutrients due to synergistic and antagonistic effects. Using scanning electron microscopy coupled with energy dispersive spectroscopy to assess the elemental distribution in A. angustifolia needles, Barbosa et al. (2017) observed that under low soil K condition, a higher Ca concentration occurs in the spongy mesophyll and more crystals containing $\mathrm{Ca}$ and $\mathrm{Mg}$ are formed, resulting in higher levels of these elements in the needles. In early studies, Simões \& Couto (1973) already had suggested a competition between $\mathrm{Ca}$ and $\mathrm{K}$ for absorption through the root system in A. angustifolia, where the lack of one favors absorption of the other. Despite the decrease in macronutrient concentrations due to K fertilization, Constantino et al. (2019) do not report reduced growth of $A$. angustifolia.

While the fertilization increased the $\mathrm{K}$ levels in needles by three times, in branches and stems, the levels increased up to seven times, indicating that these compartments are more sensitive to K. Similarly to what was observed in the needles, the application of $\mathrm{K}$ reduced the levels of $\mathrm{P}, \mathrm{Ca}$, and $\mathrm{Mg}$ in the more lignified tissues. Oppositely, the levels of $\mathrm{Al}$ and $\mathrm{Ti}$ in the branches and $\mathrm{Fe}$ and $\mathrm{Ba}$ increased in the branches and stems in function of the $\mathrm{K}$ rates.

In a pioneer work, Goor (1965) listed the levels of several nutrients in needles of A. angustifolia: N: $1.02-1.95 \% ; \mathrm{P}: 0.08$ 0.18\%; K: $0.56-2.00 \%$; Ca: 0.35 - 1.70\%; Mg: $0.05-1.70 \%$; Fe: $42-186 \mathrm{mg} \mathrm{kg}^{-1} ; \mathrm{Mn}: 18-1099 \mathrm{mg} \mathrm{kg}^{-1} ; \mathrm{Cu}: 2.2-22 \mathrm{mg} \mathrm{kg}^{-1} ; \mathrm{Zn}:$ $10-48 \mathrm{mg} \mathrm{kg}^{-1}$; and B: $10.6-42.0 \mathrm{mg} \mathrm{kg}^{-1}$. Compiling previous studies, Blum (1980) established medium foliar nutrient levels for healthy growth of $A$. angustifolia: $\mathrm{N}: 1.4-1.9 \% ; \mathrm{P}: 0.13-0.21 \%$; K: $0.8-1.51$; Ca: $0.37-1.00 \%$; Mg: $0.14-0.35 \%$. In this way, the adequate fertilization with the highest doses of $\mathrm{N}, \mathrm{P}$, and $\mathrm{K}$ guarantees adequate levels of the nutrients (Table 3,4 and 5). For Hoogh et al. (1980), the most important nutrient that limits the growth of A. angustifolia is $\mathrm{N}$, followed by the supply of $\mathrm{P}$, other nutrients like $\mathrm{K}$ and $\mathrm{Ca}$ are required in minor concentration. Based on the effect of the fertilization over the other nutrients, our results support the finds of Hoogh et al. (1980).

Table 5. Elemental composition of Araucaria angustifolia needles, branches and stem in response to potassium fertilization.

\begin{tabular}{|c|c|c|c|c|c|c|c|c|c|c|c|c|c|c|c|}
\hline \multirow[b]{2}{*}{ Var. } & \multicolumn{5}{|c|}{ Rates of $\mathrm{K}\left(\mathrm{mg} \mathrm{dm}^{-3}\right)$} & \multirow{2}{*}{ Eq. } & \multirow{2}{*}{$\mathbf{R}^{2}$} & \multirow{2}{*}{ Var. } & \multicolumn{5}{|c|}{ Rates of K $\left(\mathrm{mg} \mathrm{dm}^{-3}\right)$} & \multirow{3}{*}{ Eq. } & \multirow[b]{2}{*}{$\mathbf{R}^{2}$} \\
\hline & 0 & 117 & 234 & 469 & 938 & & & & $\mathbf{0}$ & 117 & 234 & 469 & 938 & & \\
\hline & & & & & & ------ & Jeedle & 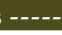 & & & & & & & \\
\hline $\mathrm{P}$ & 1.56 & 1.84 & 1.85 & 1.39 & 1.21 & $\mathrm{Q}^{*}$ & 0.66 & $\mathrm{Cu}$ & 2.67 & 2.82 & 2.49 & 2.17 & 2.16 & ns & - \\
\hline K & 4.78 & 11.00 & 14.00 & 15.00 & 14.00 & $\mathrm{Q}^{* *}$ & 0.91 & B & 15.00 & 12.00 & 9.82 & 9.15 & 9.56 & $\mathrm{~L}^{* *}$ & 0.94 \\
\hline $\mathrm{Ca}$ & 24.00 & 11.00 & 10.00 & 9.00 & 7.66 & $\mathrm{Q}^{* *}$ & 0.75 & $\mathrm{Al}$ & 87 & 97 & 112 & 78 & 88 & ns & - \\
\hline $\mathrm{Mg}$ & 6.31 & 4.02 & 3.83 & 3.43 & 3.09 & $\mathrm{Q}^{* *}$ & 0.82 & $\mathrm{Ba}$ & 26 & 15 & 13 & 16 & 19 & $\mathrm{Q}^{* *}$ & 0.59 \\
\hline $\mathrm{Fe}$ & 101 & 114 & 115 & 81 & 104 & ns & - & $\mathrm{Cd}$ & 0.20 & 0.10 & 0.15 & 0.14 & 0.14 & ns & - \\
\hline $\mathrm{Mn}$ & 427 & 161 & 147 & 199 & 190 & $\mathrm{Q}^{* *}$ & 0.52 & $\mathrm{Ti}$ & 1.40 & 1.94 & 1.66 & 1.30 & 1.82 & ns & - \\
\hline $\mathrm{Zn}$ & 14 & 15 & 12 & 11 & 12 & ns & - & & & & & & & & \\
\hline $\mathrm{P}$ & 1.17 & 1.28 & 1.22 & 1.19 & 0.93 & $\mathrm{~ns}$ & - & $\mathrm{Cu}$ & 2.38 & 2.49 & 1.95 & 2.10 & 1.82 & ns & - \\
\hline K & 1.61 & 7.34 & 8.24 & 12.00 & 12.00 & $\mathrm{~L}^{* *}$ & 0.67 & B & 11 & 15 & 14 & 14 & 13 & ns & - \\
\hline $\mathrm{Ca}$ & 12.00 & 9.15 & 8.51 & 8.38 & 6.52 & $L^{* *}$ & 0.76 & $\mathrm{Al}$ & 113 & 150 & 155 & 142 & 141 & $\mathrm{Q}^{*}$ & 0.45 \\
\hline $\mathrm{Mg}$ & 5.45 & 3.53 & 3.26 & 3.09 & 2.60 & $\mathrm{~L}^{* *}$ & 0.58 & $\mathrm{Ba}$ & 22 & 22 & 23 & 29 & 38 & $\mathrm{Q}^{*}$ & 0.98 \\
\hline $\mathrm{Fe}$ & 112 & 145 & 147 & 146 & 150 & $\mathrm{~L}^{* *}$ & 0.38 & $\mathrm{Cd}$ & 0.37 & 0.25 & 0.21 & 0.20 & 0.26 & $\mathrm{Q}^{*}$ & 0.87 \\
\hline $\mathrm{Mn}$ & 95 & 99 & 90 & 92 & 131 & ns & - & $\mathrm{Ti}$ & 2.16 & 4.06 & 3.64 & 2.91 & 3.24 & $\mathrm{Q}^{*}$ & 0.12 \\
\hline $\mathrm{Zn}$ & 13 & 15 & 14 & 19 & 14 & $\mathrm{~ns}$ & - & & & & & & & & \\
\hline $\mathrm{P}$ & 0.99 & 0.90 & 0.68 & 0.62 & 0.58 & $\mathrm{~L}^{*}$ & 0.71 & $\mathrm{Cu}$ & 2.25 & 3.00 & 1.96 & 2.07 & 1.80 & ns & - \\
\hline K & 1.74 & 4.59 & 4.34 & 7.00 & 8.05 & $\mathrm{~L}^{* *}$ & 0.83 & B & 9.85 & 11.00 & 8.78 & 8.12 & 7.45 & ns & - \\
\hline $\mathrm{Ca}$ & 7.00 & 5.06 & 4.79 & 5.21 & 4.19 & $\mathrm{~L}^{*}$ & 0.54 & $\mathrm{Al}$ & 30 & 68 & 24 & 20 & 40 & ns & - \\
\hline $\mathrm{Mg}$ & 4.03 & 2.70 & 2.49 & 2.54 & 2.30 & $\mathrm{~L}^{* *}$ & 0.46 & $\mathrm{Ba}$ & 16 & 16 & 16 & 22 & 29 & $\mathrm{Q}^{*}$ & 0.96 \\
\hline $\mathrm{Fe}$ & 24 & 53 & 28 & 16 & 83 & $\mathrm{~L}^{* *}$ & 0.42 & $\mathrm{Cd}$ & 0.12 & 0.16 & 0.05 & 0.09 & 0.06 & ns & - \\
\hline $\mathrm{Mn}$ & 59 & 58 & 42 & 53 & 77 & ns & - & $\mathrm{Ti}$ & 0.19 & 1.15 & 0.27 & 0.17 & 0.41 & ns & - \\
\hline $\mathrm{Zn}$ & 8.67 & 7.73 & 6.34 & 7.26 & 7.93 & $\mathrm{~ns}$ & - & & & & & & & & \\
\hline
\end{tabular}

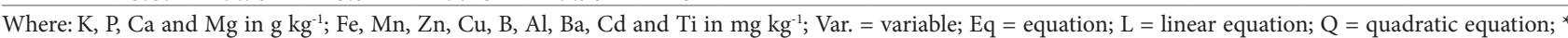
denotes $p<0.05$; ${ }^{* *}$ denotes $p<0.01$; ns (no significant). 


\section{CONCLUSION}

In this study, was evident that the use of urea as $\mathrm{N}$ supply affected the soil $\mathrm{pH}$, which probably altered the other nutrients availability. All the three plant tissues linearly responded to the $\mathrm{N}$ application. Also, the increasing in the $\mathrm{N}$ in the system led to a reduction of $\mathrm{P}$ uptake, shifting the balance between theses nutrients. The consequent changes in the C:N and C:P ratios probably will alter the biogeochemical cycle of the nutrients in the forest system, but did not represent an imbalance among the nutrients. The Mn concentration enhanced by 10 times with $\mathrm{N}$ application which should give by acidification. The application of $\mathrm{P}$ and $\mathrm{K}$ had fewer effects on the absorption of the other nutrients and heavy metal studied. Antagonism interactions were observed by $\mathrm{K} x \mathrm{Ca}, \mathrm{K}$ x Mg, resulting in large decrease their concentration by $\mathrm{K}$ application. Based on the combination of the experiments, the application of $34.4,17.5$, and $13.7 \mathrm{~kg} \mathrm{ha}^{-1}$ of N, P, and $\mathrm{K}$, respectively, must guarantee and adequate seedling development.

\section{SUBMISSION STATUS}

Received: 24 Oct. 2019

Accepted: 25 Sep. 2020

Associate editor: Eduardo Vinicius da Silva (1)

\section{CORRESPONDENCE TO}

\section{Eloá Moura Araujo}

Universidade Federal do Paraná, Departamento de Solos e Engenharia

Agrícola, Programa de Pós-graduação em Ciência do Solo, Rua Funcionários, 1540, CEP 80035-050, Curitiba, PR, Brasil

e-mail: eloamoura@alumni.usp.br

\section{REFERENCES}

Ata-Ul-Karim ST, Cang L, Wang Y, Zhou D. Interactions between nitrogen application and soil properties and their impacts on the transfer of cadmium from soil to wheat (Triticum aestivum L.) grain. Geoderma 2020; 357: 113923.

Barbosa JZ, Constantino V, Zanette F, Motta ACV, Prior SA. Soil fertility affects elemental distribution in needles of the conifer Araucaria angustifolia: A microanalytical study. Cerne 2017; 23: 257-266.

Barbosa JZ, dos Santos Domingues CR, Poggere GC, Motta ACV, dos Reis AR, de Moraes MF, Prior SA. Elemental composition and nutritional value of Araucaria angustifolia seeds from subtropical Brazil. Journal of Food Science and Technolgy. 2019; 56: 1073-1077.

Barbosa JZ, Motta ACV, Consalter R, Poggere GC, Santin D, Wendling I. Plant growth, nutrients and potentially toxic elements in leaves of yerba mate clones in response to phosphorus in acid soils. Anais da Academia Brasileira de Ciências 2018; 90: 557-571.
Blum WEH. Site - Nutrition - Growth interrelationship of Araucarias, in: Forestry Problems of the Genus Araucaria. Curitiba, pp. 119-130; 1980.

Caldeira MVW, Watzlawick LF, Soares RV, Valério AF. Teores de micronutrientes em espécies arbóreas da floresta ombrófila mista Montana-General Carneiro/PR. Ambiência 2006; 2: 29-50.

Canei AD, Hernández AG, Morales DML, da Silva EP, Souza, LF, Loss A, et al. Atributos microbiológicos e estrutura de comunidades bacterianas como indicadores da qualidade do solo em plantios florestais na Mata Atlântica. Ciência Florestal 2018; 28: 1405.

Constantino V, Barbosa JZ, Motta AV, Dolinski MA, Prior SA, Zanette F. Initial growth of Araucaria angustifolia (Bertol.) Kuntze in response to fertilization with nitrogen, phosphorus and potassium. Floresta 2019; 49: 99-108.

Deng Q, Hui D, Dennis S, Reddy KC. Responses of terrestrial ecosystem phosphorus cycling to nitrogen addition: A meta-analysis. Global Ecology and Biogeography 2017; 26: 713-728.

Embrapa. Manual de Métodos de Análise de Solo, 2nd ed. Embrapa Solos, Rio de Janeiro; 2011.

Goor CP Van. Reflorestamento com coníferas no Brasil. Rio de Janeiro; 1965.

Hess AF, Ricken P, Ciarnoschi LD. Dendrocronologia, incremento e manejo florestal em floresta de araucária - SC. Ciência Florestal 2018; 28: 1568.

Higuchi P, Silva AC da, Ferreira TDS, Souza ST de, Gomes JP, Silva $\mathrm{KM}$ da, et al. Influência de variáveis ambientais sobre o padrão estrutural e florístico do componente arbóreo, em um fragmento de Floresta Ombrófila Mista Montana em Lages, SC. Ciência Florestal 2012; 22 (1): 79-90.

Hong S, Gan P, Chen A. Environmental controls on soil pH in planted forest and its response to nitrogen deposition. Environmental Research 2019; 172: 159-165.

Hoog RJ DE. Site-nutrition-growth relationships of Araucaria angustifolia (Bert.) O. Ktze. in Southern Brazil. Universität Freiburg; 1981.

Hoogh RJ de, Goor CP van, Blum WEH. Response of planted Araucaria angustifolia to N, P, K, Ca and B fertilization, 3 and 7 years after application, in: Forestry Problems of the Genus Araucaria. Fundação de Pesquisas Florestais do Paraná, Curitiba, pp. 136-144; 1980.

Kobayashi Y, Okada, K, Mori AS. Reconsidering biodiversity hotspots based on the rate of historical land-use change. Biological Conservation 2019; 233: 268-275.

Kohler M, Niederberger J, Wichser A, Bierbaß P, Rötzer T, Spiecker H, Bauhus J. Using tree rings to reconstruct changes in soil $\mathrm{P}$ availability - Results from forest fertilization trials. Dendrochronologia 2019; 54: 11-19.

Koohkan H, Maftoun M. Effect of nitrogen- boron interaction on plant growth and tissue nutrient concentration of canola (Brassica napus L.). Journal of Plant Nutrition 2016; 39: 922-931.

Martiniano E, Silveira DO, Castro M de, Santos N, Eiji E, Weimar $\mathrm{F}$, et al. Forest ecology and management carbon-diversity hotspots and their owners in Brazilian southeastern savanna, atlantic forest 
and semi-arid woodland domains. Forest Ecology Management 2019; 452: 117575 .

Moreira-Souza M, Cardoso EJBN. Dependência micorrízica de Araucaria Angustifolia (Bert.) O. Ktze. sob doses de fósforo. Revista Brasileira de Ciência do Solo 2002; 26: 905-912.

Motta ACV, Serrat BM, Reissmann CB, Dionísio JA. Micronutrientes na rocha, no solo e na planta. Curitiba; 2007.

Netzer F, Pozzi L, Dubbert D, Herschbach C. Improved photosynthesis and growth of poplar during nitrogen fertilization is accompanied by phosphorus depletion that indicates phosphorus remobilization from older stem tissues. Environmental Experimental Botany 2019; 162: 421-432.

Orellana E, Vanclay JK. Could native Araucaria forests be managed for timber production on small farms in southern Brazil? Forest Ecology Management 2018a; 430: 1-9.

Orellana E, Vanclay JK. Competition and dominance between angiosperms and Araucaria angustifolia (Bert.) O. Kuntze in the Atlantic Forest in southern Brazil. Forest Ecology Management 2018b; 425: 119-125.

Peñuelas J, Sardans J, Rivas-ubach A, Janssens IA. The humaninduced imbalance between C, N and P in Earth's life system. Global Change Biology 2012; 18: 3-6.
Rhodes JR, Cattarino L, Seabrook L, Maron M. Assessing the effectiveness of regulation to protect threatened forests. Biological Conservation 2017; 216: 33-42.

Ricken P, Hess AF, Borsoi GA. Relações biométricas e ambientais no incremento diamétrico de Araucaria angustifolia no planalto serrano catarinense. Ciência Florestal , 2018; 28: 1592.

Sarkkola S, Ukonmaanaho L, Nieminen TM, Laiho R, Laurén A, Finér, L, Nieminen M. Should harvest residues be left on site in peatland forests to decrease the risk of potassium depletion? Forest Ecology Management 2016; 374: 136-145.

Scheeren LW, Finger CAG, Schumacher MV, Longhi SJ. Crescimento em altura de Araucaria angustifolia (Bert.) O. Ktze. em três sítios naturais, na região de Canela (RS). Ciência Florestal 1999; 9: 23.

Simões JW, Couto HTZ. Efeitos da omissão de nutrientes na alimentação mineral do pinheiro do Paraná Araucaria Angustifolia (BERT.) O. KTZE cultivado em vaso. Ipef 3-39; 1973.

Yuan ZY, Chen HYH. Decoupling of nitrogen and phosphorus in terrestrial plants associated with global changes. Nature Climate Change 2015; 5: 465-469. 